\title{
Type distribution of human papillomavirus in HIV- infected women with cervical intraepithelial neoplasia (CIN) stages 2 and 3 in Botswana
}

\author{
Doreen Ramogola-Masire ${ }^{1,2^{*}}$, Nicola M Zetola ${ }^{1,2}$, Veronica de Klerk², Barati Monare ${ }^{2}$, Bakgaki Ratshaa², \\ Gracious Ditlhabang ${ }^{2}$, Elisabeth Chibaya ${ }^{2}$, Metlha Nchunga², Mukendi K Kayembe ${ }^{3}$, Kurt T Barnhart ${ }^{1}$, \\ Cindy M McGrath ${ }^{1}$, Harvey M Friedman ${ }^{1,2}$
}

From $12^{\text {th }}$ International Conference on Malignancies in AIDS and Other Acquired Immunodeficiencies (ICMAOI)

Bethesda, MD, USA. 26-27 April, 2010

\section{Background}

Human papillomavirus (HPV) vaccines containing types 16 and 18 are remarkably effective in preventing cervical cancer associated with these HPV types. No information currently exists in Botswana concerning the HPV types causing precancerous or cancerous lesions.

\section{Methods}

The goal of this pilot project was to determine the HPV types causing precancerous cervical intraepithelial neoplasia (CIN) stages 2 and 3 in HIV-infected women in Gaborone, Botswana. HIV-infected women referred to our clinic with high-grade intraepithelial lesion (HSIL) on the Pap smear were enrolled in the study. Two specimens were obtained on all subjects, one for histopathology and the other for HPV typing. HPV typing was performed only if the histopathology results demonstrated CIN stage 2 or 3 disease. Histopathology results were corroborated at two sites: Lancet Laboratories (Johannesburg, South Africa) and University of Pennsylvania (Pennsylvania, United States). HPV typing was performed using linear array genotyping (CE-IVD, Roche Diagnostics).
*Correspondence: doreen.masire@gmail.com

'Department of Medicine, University of Pennsylvania, Philadelphia, PA, USA

Full list of author information is available at the end of the article

\section{Results}

This is an interim analysis of an intended sample size of 100 women. We identified 30 HIV-infected women with CIN stages 2 or 3 between August 11, 2009, and January 29, 2010. The median age was 36 (interquartile range [IQR], 33 - 38) and the median CD4 cell count was 427 cells $/ \mathrm{mm}^{3}$ (IQR, 360-560 cells $/ \mathrm{mm}^{3}$ ). Of the 30 women enrolled, 28 (93\%) had co-infection by multiple HPV types. HPV type 52 was found in the $2(7 \%)$ women carrying a single type. $15(50 \%)$ had HPV types 16,18 , or both. $25(83 \%)$ women, including all the ones not carrying the 16 or 18 types, carried other high-risk HPV types. Among the other high-risk types, HPV types 33, 35, and 58 were the most prevalent, accounting for 7 (23\%), 8 (27\%), and 10 (33\%) cases, respectively.

\section{Conclusion}

HPV 16 and 18 are the most common types in HIVinfected women with CIN 2 or 3 in Gaborone, Botswana. However, other high-risk HPV types may account for a significant number of advanced CIN lesions in this population.
Acknowledgements

This article has been published as part of Infectious Agents and Cancer Volume 5 Supplement 1, 2010: Proceedings of the $12^{\text {th }}$ International Conference on Malignancies in AIDS and Other Acquired Immunodeficiencies (ICMAOI). The full contents of the supplement are available online at http://www.biomedcentral.com/1750-9378/5? issue=S1. 


\section{Author details}

${ }^{1}$ Department of Medicine, University of Pennsylvania, Philadelphia, PA, USA.

${ }^{2}$ Botswana-UPenn Partnership, Gaborone, Botswana. ${ }^{3}$ National Health

Laboratory, Gaborone, Botswana.

Published: 11 October 2010

doi:10.1186/1750-9378-5-S1-A83

Cite this article as: Ramogola-Masire et al:: Type distribution of human

papillomavirus in HIV-infected women with cervical intraepithelial

neoplasia (CIN) stages 2 and 3 in Botswana. Infectious Agents and Cancer 2010 5(Suppl 1):A83.

Submit your next manuscript to BioMed Central and take full advantage of:

- Convenient online submission

- Thorough peer review

- No space constraints or color figure charges

- Immediate publication on acceptance

- Inclusion in PubMed, CAS, Scopus and Google Scholar

- Research which is freely available for redistribution

Submit your manuscript at 